fully equipped to come back to the Edinburgh Garden, this time on the staff of H.M. Office of Works as deputy keeper.

Up to this stage his published work had not been voluminous, but now a flood commenced. Descriptions of new species and now genera came quickly. Soon the interest tended to canalize in Primula and Rhododendron. With more and more material pouring in from the travels of George Forrest and others, Edinburgh was soon forced into the front rank of those centres where plant systematy received most attention.

In 1922 Sir Isaac Bayley Balfour resigned from his dual appointment and Wright Smith took over the duties of the University chair and the keepership of the Garden-both Crown appointments. Thus he laboured for thirty-four years-he was among the last, if not quite the last, professor to receive his appointment in Scotland "for life while of good conduct". He taught his classes with ever-welling enthusiasm, inspired his joint staff to new exertions, and all the time dealt with the multifarious affairs of a large busy botanical garden. With all this he carried on his research in his beloved genus Primula.

Space precludes more than the merest mention of the many other facets of the man and his careerhis love of games (beating youngsters at chess or tennis in his last decade); his joy in company and the stories he told; his deep love of India and the Indians (all from that continent were Indians, partition was in neither his vocabulary nor his geography).

He was created knight in 1932 and was elected Fellow of the Royal Society in 1945. Among many other honours he was an honorary LL.D. of Aberdeen and D. ès Sc. of Toulouse. He was awarded the Victoria Medal of Honour by the Royal Horticultural Society in 1925 and succeeded Dr. A. B. Rendle as the Society's professor of botany in 1938. He was also president of the Royal Society of Edinburgh during 1944-49.

Sir William Wright Smith will be mourned deeply by very many, and his work will provide an enduring memorial. $\mathrm{H}_{\Theta}$ is survived by his widow and three daughters. Alexander Nelson

\section{Brigadier W. H. Evans, C.S.I., C.I.E.}

Brigadier Wullam Harry Evans belonged to that rapidly dwindling band of army officers who turned to natural history as a hobby while serving in the Indian sub-continent, and in the process added significantly to our knowledge of its fauna and flora. 'The son of General Sir Horace Evans, he was born in Assam in 1876. Educated at King's College, Canterbury, he joined the Royal Engineers in 1894. He served with the Somaliland Field Force in 1903-4 and throughout the First World War, sustaining injuries in both campaigns. Though he made light of these, they did in fact increasingly handicap him in later years. $\mathrm{He}$ died after a short illness on November 13.

Throughout his service in India, Evans collected butterflies assiduously, eventually presenting his entire collection to the Trustees of the British Museum. His keenly analytical mind, however, soon rebelled at the inconvenience of the literature available which, though voluminous and often profusely illustrated, was scattered and costly and largely devoid of a comparative element. Soon after publishing an account of the butterflies of the Palni Hills and a most useful "List" of the butterflies of India, he embarked upon a thorough taxonomic overhaul of the Rhopalocera of India, Burma and Ceylon. His results were published in instalments in the Journal of the Bombay Natural History Society, and afterwards re-issued in book form in 1927. These "Keys for the Identification of Indian Butterflies", though at first sight disconcerting, due to systems of numbering and abbreviation of Evans's own devising, proved so practical and popular that a second edition was called for in 1932. In a single handy book of 300 pages, illustrated by thirty-two not at all beautiful half-tone plates, they gave the student just that essential information which he would fail to find in the ten large volumes of Moore's "Lepidoptera Indica". These "Keys" have proved invaluable, and at family and generic level useful beyond the range of their immediate objective.

On retirement in 1931, Evans devoted himself voluntarily to the single task of applying his methods to the taxonomic revision of the Hesperiidae or 'Skippers' of the world, a group worthy of his metal that had hitherto defied all attempts at a satisfactory natural classification, due less to the very large number of species concerned than to the remarkable uniformity of the morphological characters most easily used in classification. His results were published by the Trustees in a series of "Catalogues of the Hesperiidae in the British Museum", issued in 1937 (Africa), 1949 (Europe, Asia and Australia) and 1951-55 (America). During the course of this work Evans must have examined upwards of half a million specimens and, because his classification is largely based on the external male genitalia, dissected a large proportion of them. To achieve this in the time at his disposal he had to use methods less elaborate than ideal, and there is no doubt that a more leisurely re-examination of his results will lead to considerable revision in detail. Nevertheless, he did for the first time apply critically the same standards to the whole family in assessing the taxonomic values of morphological characters. Such a consistent application of uniform criteria has produced for the first time in this most difficult but attractive family an orderly and, one believes, natural arrangement of strictly comparable units which is unlikely to be superseded for many years and from which further research can proceed. He himself would have been the last to claim that he had achieved finality.

Evans's numerous entomological friends in Britain and abroad will feel his loss for many years to come; but he has at least left them a massive and characteristic contribution of lasting value by which to remember him.

N. D. RILEY

\section{Prof. St. Maziarski}

Prof. St. Maziarski, a well-known Polish histologist, died in Cracow on July 7, 1956, at the age of eighty-three. He was the initiator of the so-called Cracow school of histology and worked chiefly in the field of the cytology of glands and the microscopical anatomy of the muscular tissue. He was the pupil of the French histologist, A. Prénant, and a friend of P. Bouin. All his life he was connected with the Jagellonian University of Cracow ; for several periods he served as dean of the Medical Faculty, and he was rector of the School during 1933-36. 